\title{
Production of Chitin and Chitosan from Partially Autolyzed Shrimp Shell Materials
}

\author{
Nguyen Van Toan ${ }^{*}$ \\ School of Biotechnology, International University, Ho Chi Minh City, Vietnam; Vietnam National University, Ho Chi \\ Minh City, Vietnam
}

\begin{abstract}
The effect of partial autolysis during storage of shrimp biowaste on the quality of the extracted chitin and chitosan has been investigated. Shrimp waste materials were stored in a $30^{\circ} \mathrm{C}$ incubator for $1-4$ days. The quality of the chitin and chitosan extracted from these materials was assessed by ash and protein analysis and in solution by viscosimetry. Chitosan from fresh biowaste, treated for 1 day at $30^{\circ} \mathrm{C}$ showed the highest viscosity $3590 \mathrm{cps}$. Chitosan from frozen material showed the highest viscosity at $3580 \mathrm{cps}$ after 2 days at $30^{\circ} \mathrm{C}$. The corresponding values for chitosan without $30^{\circ} \mathrm{C}$ treatment were 2300 and $2700 \mathrm{cps}$. Normally, viscosity, solubility and molecular weight of chitosan are closely related. The data of this study show that after partial autolysis the viscosity of the chitosan obtained has increased, but that other characteristics of chitosan such as degree of deacetylation, molecular weight, solubility and turbidity did not change.
\end{abstract}

Keywords: Chitin, chitosan, decay, partial autolysis, improper storage, viscosity.

\section{INTRODUCTION}

The crude shrimp head and skin materials have only a low economical value and are treated as biowaste or sold to animal feed manufacturers [1]. The shrimp biowaste in the tropical region contains $10-20 \%$ calcium, 30-65\% protein content and $8-10 \%$ chitin on a dry basis [2]. Chitosan, which is obtained by $\mathrm{N}$ - deacetylation of chitin, has attracted attention due to its unique cationic character. Typically, chitosan is produced from waste generated from crustacean processing (e.g. shrimp and crab). Chitin and its derivative chitosan are of commercial interest due to their excellent biocompatibility, biodegradability, non-toxicity, chelating and adsorption power. With these characteristics, especially chitosan has many attractive applications in biotechnology, food and pharmaceutical industry, in cosmetics, environmental engineering, in agriculture and aquaculture. Though chemical procedures are widely used to produce chitin and chitosan utilizing shrimp waste as raw material [3], there is not much information how to improve the production process so as to produce chitosan with consistent quality, especially from stored material sources. The purpose of this study is to include partial autolysis in the existing protocol in order to improve the quality of chitosan product. This paper describes experiments to determine a suitable process for chitin/chitosan production from partially autolysed shrimp shell and suggests utilizing shrimp shells that have softened and partially degraded under carefully defined conditions.

\section{MATERIALS AND METHODS}

Shrimp shells from black tiger shrimp (Penaeus monodon) were provided by a local shrimp processing

*Address correspondence to this author at the School of Biotechnology, International University, Vietnam National University, Ho Chi Minh City; Fax:+84-83-7244271; Email: nvtoan@hcmiu.edu.vn factory. The shrimp shells were collected in big plastic bags with addition of ice to preserve the shrimp shell from decomposition. During transportation to the laboratory (transport time was only one and a half hour), the shrimp waste was kept cool and in the dark to avoid effects of direct sunlight. After arrival, the shrimp waste was directly used to produce chitosan as specified below. In this paper shrimp shell without further treatment is named fresh shrimp shell, shrimp shell stored in the freezer (at minus $18^{\circ} \mathrm{C}$ ) for several months is named frozen shrimp shell.

Various procedures have been adopted to obtain high quality chitin by removing protein, inorganic material (mainly $\mathrm{CaCO} 3$ ) and pigments and lipid. Demineralization is usually carried out by treatment with $\mathrm{HCl}$ and deproteination by treatment with $\mathrm{NaOH}$ but other researchers have used other methods as well. The sequence of these processes has been varied, although in most chitin producing industries deproteination is carried out prior to demineralization [4]. In this research a modified method has been used in which shrimp shell was allowed to undergo partial autolysis before it was used to produce chitin and chitosan. The selected autolysis times were 1, 2, 3 and 4 days. Fresh shrimp shell used as the control for this experiment is marked as 0 day treatment (Fig. 1). The autolyzed shrimp shell was demineralized with $0.68 \mathrm{M} \mathrm{HCl}$ solution $(1: 5 \mathrm{w} / \mathrm{v})$ at ambient temperature $\left(28-32^{\circ} \mathrm{C}\right)$ for $12 \mathrm{~h}$. The residue was washed and soaked in tap water for 6-8 h. It was then dewatered and deproteinized with $0.62 \mathrm{M} \mathrm{NaOH}$ solution $(1: 5 \mathrm{w} / \mathrm{v})$ at ambient temperature for $20 \mathrm{~h}$.

The chitin obtained from the revised process above was deacetylated in $12.5 \mathrm{M} \mathrm{NaOH}(1: 5 \mathrm{w} / \mathrm{v})$ solution at $65^{\circ} \mathrm{C}$ for $20 \mathrm{~h}$. After deacetylation, the chitosan was washed and dried in sunlight and assayed for moisture content, ash content, protein content, degree of deacetylation, viscosity, solubility, turbidity and molecular weight [5]. The protein content in the chitosan sample was determined using the micro-biuret 
(a) Common scheme for chitin/chitosan production

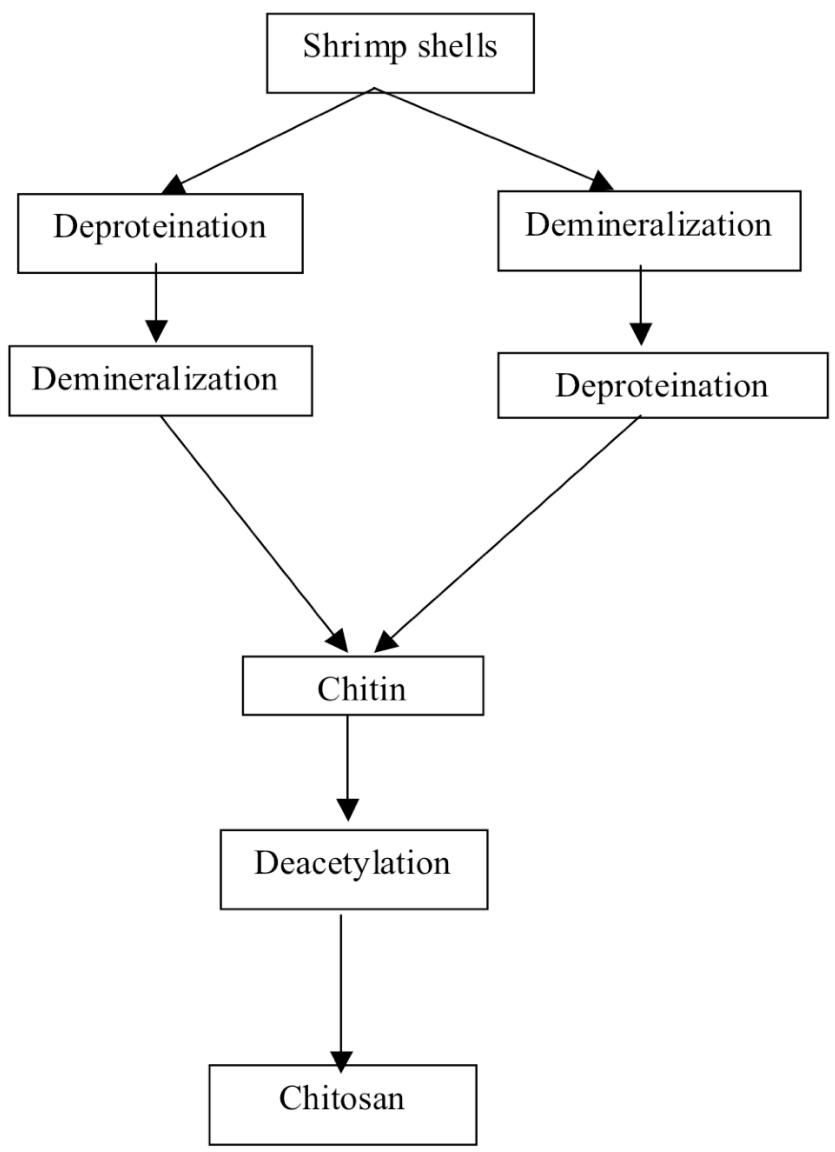

(b) Scheme under this study

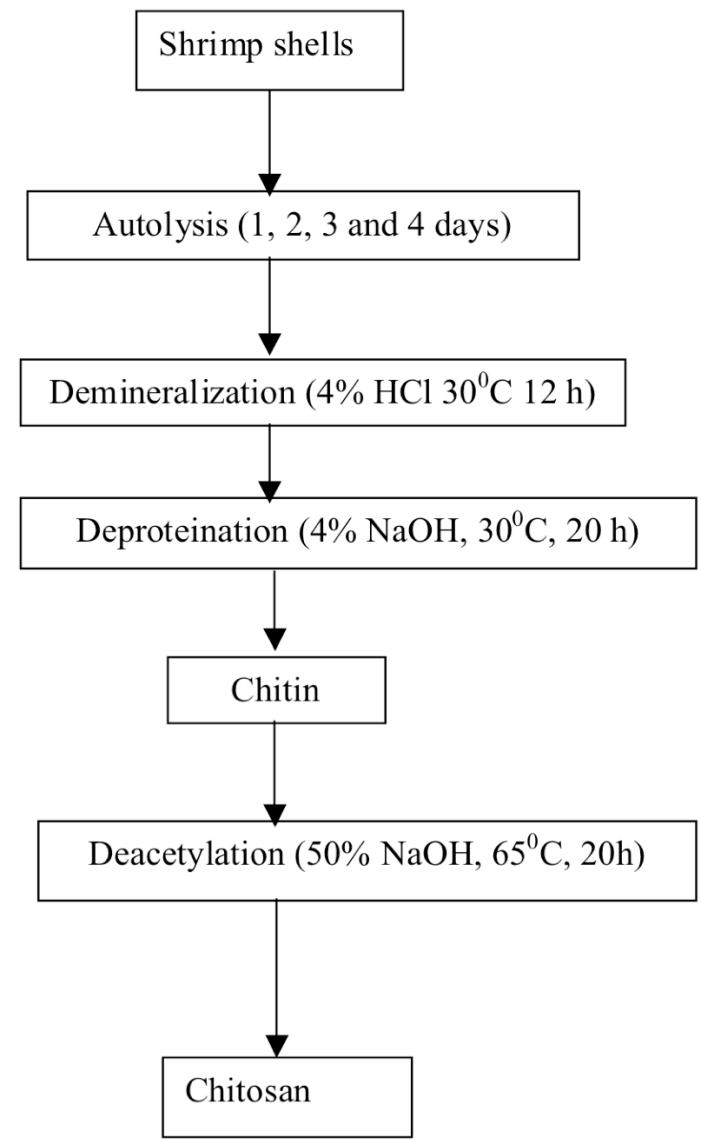

Fig. (1). A comparison between (a) the common process and (b) revised process under this study for the production of chitin and chitosan.

method [6]. The degree of deacetylation was analyzed by first derivative ultraviolet (UV) spectrophotometry [7]. Weight average molecular weight was determined by gel permeation chromatography (Waters GPC) with a differential refractometer detector. Dextrans of various molecular weights ranging from $9.9 \times 10^{3}$ to $2 \times 10^{6} \mathrm{Kd}$ were used as standards. Ash content was determined by the standard AOAC method [8]. Various physico-chemical criteria were investigated under standard conditions, for chitosan in a $1 \%$ solution in $0.35 \mathrm{M}$ acetic acid. Turbidity was assessed using a turbidity meter (Model 2100P portable turbidity meter, HACH Company, USA) and viscosity by a Brookfield Model DV - VII + Viscometer. Solubility was measured using the transglucosidase method [9]: the $\mathrm{pH}$ of $50 \mathrm{ml} 1 \%(\mathrm{w} / \mathrm{v})$ chitosan solution was adjusted to 4.8 with $30 \% \quad(\mathrm{w} / \mathrm{v})$ sodium acetate. Transglucosidase L-500 (Genencor International, $500 \mu 1$ ) was added. After incubation at $60^{\circ} \mathrm{C}$ for $24 \mathrm{~h}$, the insoluble material was collected by filtration using a pre-weighed Whatmann $\mathrm{GF} / \mathrm{C}$ filter paper $(1.2 \mu \mathrm{m})$. The filter paper was dried and weighed and the amount of insoluble material was calculated from its weight gain.

\section{RESULTS AND DISCUSSION}

\section{Characterization of Chitosan Samples}

The deproteinized and demineralized shrimp shell, chitin, was assayed for ash and protein content to check if the two critical values are below the level of $1 \%$. For chitosan, product properties such as the degree of deacetylation, solubility and turbidity were assessed to characterize the preparations. Table 1 shows the ash and protein content in the chitin samples.

Table1. Ash and Protein Content of Chitin

\begin{tabular}{|c|c|c|c|c|}
\hline \multirow{2}{*}{ Sample } & \multicolumn{2}{|c|}{ Ash Content* (\%) } & \multicolumn{2}{c|}{ Protein Content** (\%) } \\
\cline { 2 - 5 } & Fresh & Frozen & Fresh & Frozen \\
\hline \hline Chitin 0 & $0.67 \pm 0.02$ & $0.40 \pm 0.05$ & $0.83 \pm 0.16$ & $0.65 \pm 0.08$ \\
\hline Chitin 1 & $0.61 \pm 0.16$ & $0.51 \pm 0.04$ & $0.78 \pm 0.06$ & $0.58 \pm 0.05$ \\
\hline Chitin 2 & $0.67 \pm 0.11$ & $0.41 \pm 0.04$ & $0.84 \pm 0.12$ & $0.48 \pm 0.04$ \\
\hline Chitin 3 & $0.71 \pm 0.06$ & $0.53 \pm 0.04$ & $0.55 \pm 0.06$ & $0.45 \pm 0.04$ \\
\hline Chitin 4 & $0.77 \pm 0.02$ & $0.97 \pm 0.04$ & $0.61 \pm 0.01$ & $0.41 \pm 0.06$ \\
\hline
\end{tabular}

Chitin/chitosan $0,1,2,3,4$ indicates $0,1,2,3,4$ days of shrimp shell autolysis.

$*$ The ash content of the original shells was $24.5 \%(\mathrm{db})$.

** The protein content of the original shell was $23.5 \%(\mathrm{db})$.

Chitosan samples obtained from the two different production schemes were characterized and compared with each other. All chitosan samples had a uniform quality with less than $1 \%$ protein content (by microbiuret assay), less then $1 \%$ ash and about $8-10 \%$ moisture content. Most samples had a degree of deacetylation close to $90 \%$, solubility near $100 \%$ and turbidity $20 \sim 22$ NTU. Data on solubility, turbidity, degree of deacetylation and molecular weight 
Table 2. Properties of Chitosan Produced from Fresh Shrimp Shells

\begin{tabular}{|c|c|c|c|c|c|c|c|}
\hline \multirow{2}{*}{ Sample } & \multicolumn{7}{|c|}{ Characteristics of Chitosan Produced from Fresh Shrimp Shells } \\
\cline { 2 - 8 } & $\begin{array}{c}\text { Ash Content } \\
(\%)\end{array}$ & $\begin{array}{c}\text { Protein } \\
\text { Content (\%) }\end{array}$ & Solubility (\%) & $\begin{array}{c}\text { Degree of } \\
\text { Deacetylation (\%) }\end{array}$ & $\begin{array}{c}\text { Turbidity } \\
(\mathbf{N T U )}\end{array}$ & $\begin{array}{c}\text { Viscosity } \\
(\mathbf{c p s )}\end{array}$ & $\begin{array}{c}\text { Molecular Weight } \\
(\text { Dalton x10 }\end{array}$ \\
\hline \hline Chitosan 0 & $0.68 \pm 0.07$ & $0.86 \pm 0.06$ & $98.8 \pm 0.22$ & $88.1 \pm 0.12$ & $21.5 \pm 0.58$ & $2200 \pm 66$ & $1.71 \pm 0.03$ \\
\hline Chitosan 1 & $0.78 \pm 0.04$ & $0.73 \pm 0.05$ & $98.5 \pm 0.42$ & $88.6 \pm 0.18$ & $20.6 \pm 0.75$ & $3590 \pm 66$ & $1.72 \pm 0.02$ \\
\hline Chitosan 2 & $0.51 \pm 0.03$ & $0.94 \pm 0.01$ & $98.6 \pm 0.24$ & $86.2 \pm 0.18$ & $20.4 \pm 0.48$ & $2540 \pm 80$ & $1.74 \pm 0.02$ \\
\hline Chitosan 3 & $0.27 \pm 0.06$ & $0.53 \pm 0.06$ & $98.7 \pm 0.13$ & $88.0 \pm 0.20$ & $21.3 \pm 0.50$ & $1230 \pm 23$ & $1.70 \pm 0.02$ \\
\hline Chitosan 4 & $0.61 \pm 0.02$ & $0.57 \pm 0.01$ & $97.7 \pm 0.06$ & $86.7 \pm 0.14$ & $21.5 \pm 0.41$ & $1120 \pm 65$ & $1.72 \pm 0.03$ \\
\hline
\end{tabular}

Table3. Properties of Chitosan Produced from Frozen Shrimp Shells

\begin{tabular}{|c|c|c|c|c|c|c|c|}
\hline \multirow{2}{*}{ Sample } & \multicolumn{7}{|c|}{ Characteristics of Chitosan Produced from Frozen Shrimp Shells } \\
\cline { 2 - 8 } & $\begin{array}{c}\text { Ash Content } \\
(\%)\end{array}$ & $\begin{array}{c}\text { Protein Content } \\
(\%)\end{array}$ & Solubility (\%) & $\begin{array}{c}\text { Degree of } \\
\text { Deacetylation (\%) }\end{array}$ & $\begin{array}{c}\text { Turbidity } \\
\text { (NTU) }\end{array}$ & $\begin{array}{c}\text { Viscosity } \\
\text { (cps) }\end{array}$ & $\begin{array}{c}\text { Molecular Weight } \\
\text { (Daltonx10 }\end{array}$ \\
\hline \hline Chitosan 0 & $0.37 \pm 0.05$ & $0.66 \pm 0.04$ & $98.6 \pm 0.06$ & $87.1 \pm 0.82$ & $22.1 \pm 0.25$ & $2720 \pm 323$ & $1.70 \pm 0.05$ \\
\hline Chitosan 1 & $0.55 \pm 0.04$ & $0.56 \pm 0.04$ & $97.9 \pm 0.06$ & $88.3 \pm 0.33$ & $20.5 \pm 0.42$ & $2060 \pm 63$ & $1.72 \pm 0.04$ \\
\hline Chitosan 2 & $0.60 \pm 0.04$ & $0.48 \pm 0.04$ & $98.7 \pm 0.07$ & $89.8 \pm 0.19$ & $20.2 \pm 0.25$ & $3580 \pm 471$ & $1.75 \pm 0.04$ \\
\hline Chitosan 3 & $0.30 \pm 0.04$ & $0.38 \pm 0.04$ & $98.8 \pm 0.13$ & $89.4 \pm 0.92$ & $21.4 \pm 0.52$ & $1950 \pm 152$ & $1.71 \pm 0.05$ \\
\hline Chitosan 4 & $0.27 \pm 0.04$ & $0.41 \pm 0.05$ & $98.8 \pm 0.15$ & $88.9 \pm 0.30$ & $21.4 \pm 0.48$ & $2090 \pm 280$ & $1.71 \pm 0.02$ \\
\hline
\end{tabular}

indicate that there are no significant differences in these parameters among all treatments for the chitosan produced from fresh and frozen shrimp shell. There are, however, differences in the ash content, protein content and in particular, in the viscosity of chitosan solutions (Tables 2 and 3).

The protein content of chitosan samples in all treatments are well below 1\% (Tables 2 and 3 ). The protein content ranges from $0.53 \%$ to $0.94 \%$ and $0.38 \%$ to $0.66 \%$ for the fresh and frozen shrimp shells, respectively. It can be seen that the protein content of chitosan produced from fresh shrimp shells is higher than that of frozen shrimp shells in every treatment. This may be because of the matrix of protein and another component in the shrimp shell is softened by the freezing procedure. The frozen shell might have a more open structure in which the matrixes of proteins, inorganic materials and lipids have already been weakened during the storage time. Hence, it allows $\mathrm{NaOH}$ solution to easily breakdown the protein and to remove it from the shell. The same phenomenon has been observed when using $\mathrm{HCl}$ solution to demineralize inorganic materials from shrimp shells.

\section{The Phenomenon of Improved Chitosan Quality After Partial Autolysis}

Limited autolysis of shrimp biomaterial has a positive effect on the quality of the extracted chitin and chitosan. The data presented in this paper show that demineralization becomes somewhat more efficient, protein removal is facilitated and the viscosity of the chitosan is significantly enhanced.
Regarding demineralization, it was also observed that after partial autolysis mineral removal can be achieved under more mild conditions. Normally, the demineralization process is conducted in $1 \mathrm{M} \mathrm{HCl}$ for a period of $12 \mathrm{~h}$. As shown for partial autolyzed material in Table 4 , even $0.5 \mathrm{M}$ $\mathrm{HCl}$ can reduce the ash content to less than $1 \%$ within $6 \mathrm{~h}$ of treatment.

Table 4. The Ash Content of Chitosan Samples

\begin{tabular}{|c|c|c|}
\hline \multirow{2}{*}{$\begin{array}{c}\text { Description of } \\
\text { Demineralization }\end{array}$} & \multicolumn{2}{|c|}{ Ash Content (\%) } \\
\cline { 2 - 3 } & $\begin{array}{c}\text { Fresh/1 Day } \\
\text { Autolysis* }\end{array}$ & $\begin{array}{c}\text { Frozen/2 Days } \\
\text { Autolysis** }\end{array}$ \\
\hline \hline $0.5 \mathrm{M} \mathrm{HCl}$ for $6 \mathrm{hrs}$ & $0.79 \pm 0.02$ & $0.71 \pm 0.01$ \\
\hline $0.5 \mathrm{M} \mathrm{HCl}$ for $12 \mathrm{hrs}$ & $0.72 \pm 0.03$ & $0.67 \pm 0.01$ \\
\hline
\end{tabular}

* Starting with fresh biomaterial, autolyzed at $30^{\circ} \mathrm{C}$ during 1 day.

** Starting with frozen biomaterial, autolyzed at $30^{\circ} \mathrm{C}$ during 2 days.

Demineralization might be improved by partial autolysis due to a direct action on $\mathrm{CaCO}_{3}$ or by an action on the protein scaffold, resulting in an improved exposure of the $\mathrm{CaCO}_{3}$. For the industrial practice of chitin extraction this means that a shorter time and lower concentration of $\mathrm{HCl}$ may suffice and that damage due to hydrolytic action of $\mathrm{HCl}$ on the polymer backbone structure of chitin can be reduced.

Following partial autolysis, deproteination is more efficient as well. The protein content after treatment of autolyzed biomaterial with $2 \% \mathrm{NaOH}$ is similar to the protein content after standard $4 \% \mathrm{NaOH}$ treatment. More 
surprisingly, it took not more than $6 \mathrm{~h}$ to obtain a residual protein level of $0.31 \%$. Apparently partial autolysis changes the chemical structure of the shell tissue, resulting in a higher sensitivity for the alkali mediated peptide hydrolysis. Since low concentration of alkali is equally effective, the cost of deproteination in industry and the environmental impact of this treatment will be reduced.

Partial autolysis also results in a chitosan product with a higher viscosity. This has been observed for fresh chitosan kept during 1 day at $30^{\circ} \mathrm{C}$ degrees as for chitosan from frozen material, stored 2 days at $30^{\circ} \mathrm{C}$ degrees. This could be caused by a variety of factors. The processing procedure has been investigated in detail to reveal variables that might explain this peculiar phenomenon. The most realistic explanation is that as result of autolysis, all steps in the chemical treatment of the biowaste are facilitated allowing for the extraction of a chitosan with a minimum of chemical damage. As a result the chitosan will be isolated in its best form and generate upon dissolution a high viscosity.

\section{CONCLUSIONS}

The viscosity of a chitosan sample is a crucial parameter that indicates the quality of the chitosan sample. From the results obtained through this study, it can be concluded that chitosan samples with an enhanced viscosity can be obtained when the shrimp biowaste is allowed to a limited decay. In particular, the viscosity of chitosan samples extracted from fresh shells and treated for 1 day and from frozen shells treated for 2 days show a remarkable higher viscosity.

Normally, viscosity, solubility and molecular weight of chitosan are closely related. But the result of this study shows that in spite of the increase of the viscosity, other characteristics of chitosan such as the degree of deacetylation, molecular weight, solubility and turbidity have not changed compared to the chitosan from fresh material.

\section{ACKNOWLEDGEMENT}

The author would like to express his thanks to the International University, Vietnam National University, Ho Chi Minh City for generous financial support.

\section{REFERENCES}

[1] Suchiva K, Chandrkrachang S, Methacanon P, Peter MG. Proceedinggs of the $5^{\text {th }}$ Asia Pacific Chitin and Chitosan Symposium \& Exhibition. Bangkok, Thailand 2002.

[2] Rao MS, Yu P, Stevens WF, Chandrkrachang S, Kungsuwan A, Hall GM. The Proceedinggs of the Second Asia Pacific Chitin and Chitosan Symposium; November 1996; Bangkok, Thailand 1996.

[3] Domard A, Roberts GAF, Vårum KM, Eds. Chitosan production routes and their role in determining the structure and properties of the product. Lyon, France; Jacquers Andre Publisher 1997.

[4] Roberts GAF. Preparation of chitin and chitosan. The Macmillan. UK: London Press 1992.

[5] Trung TS, Thein-Han WW, Qui NT, Ng CH, Stevens WF. Functional characteristics of shrimp chitosan and its membranes as affected by the degree of deacetylation. Bioresour Technol 2006 97(4): 659-63.

[6] Uragami T, Kurita K, Fukamizo T, Eds. Chitin and chitosan in lifescience. Tokyo: Kodansha Scientific Ltd 2001.

[7] Muzzarelli RAA, Rochetti R. Determination of the degree of deacetylation of chitosan by first derivative ultraviolet spectrophotometry. J Carbohydr Polym 1985; 5: 461-72.

[8] AOAC. Official methods of analysis, $14^{\text {th }}$ ed. Association of Official Analytical Chemists, Washington, DC 1984; pp. 64-90.

[9] Hein S, Ng CH, Stevens WF. Quantification and characterization of insoluble chitinous materials in viscous chitosan solutions. Biotechnol Lett 2003; 25: 863-8. 